\title{
CHARACTERIZATION OF MANGABEIRA TREES AND FRUITS IN THE SAVANNAH-RESTINGA TRANSITION ZONE
}

\author{
LARISSA DE PAULA VIANA DA SILVA², JOSÉ RIBAMAR GUSMÃO ARAUJO ${ }^{3}$, \\ ARIADNE ENES ROCHA ${ }^{3}$, MARY JANE NUNES CARVALHO ${ }^{4}$, HEDER BRAUN ${ }^{3}$, \\ MÁRIO LUIZ RIBEIRO MESQUITA ${ }^{3}$
}

\begin{abstract}
Brazil is the third largest fruit producer in the world, but many native fruits remain underexploited, as is the case for mangabeira (Hancornia speciosa Gomes). Little is known about general aspects of this species in its naturally occurring environment. Thus, this study aimed to characterize plant and fruit morphologies from native mangabeira selections in the Savannah-Restinga vegetation transition zone. The experiment was carried out in Patizal, Recanto and Recurso villages located in the Morros municipality, Maranhão State, dominated by extensive Savannah-Restinga vegetation transition zone with naturally occurring mangabeiras. Forty five mangabeira trees were randomly chosen from native selections in the three villages. Data collected were plant height, stem height, stem diameter, canopy volume, number of main and secondary branches and number of fruits. Twenty fruits were collected per plant to determine the mass, length and diameter, pulp and skin mass, pulp yield, seed number and seed mass. There was a high degree of variability for all assessed variables except for the pulp yield (average $=86.69 \%$, minimum $=76.75 \%$ and maximum $=91.11 \% ; \mathrm{CV}=3.51 \%$ ). Significant and positive high magnitude correlations were noted among the variables of fruit mass and pulp mass plus skin with seed number $(r=0,01 ; \rho \leq 0,78$ e $\rho \leq 0,74$, respectively).
\end{abstract}

Index terms: Hancornia speciosa Gomes, native selections, biometry.

\section{CARACTERIZAÇÃO DE ÁRVORES E FRUTOS DE MANGABEIRA NA ZONA DE TRANSIÇÃO CERRADO-RESTINGA}

\begin{abstract}
RESUMO - O Brasil é o terceiro maior produtor de frutas do mundo, porém muitas fruteiras nativas continuam subexploradas, como ocorre com a mangabeira (Hancornia speciosa Gomes). Pouco se conhece sobre os aspectos gerais da espécie em seus ambientes de ocorrência natural. Desta forma, objetivou-se caracterizar a morfologia da planta e do fruto de mangabeiras silvestres selecionadas em áreas de ocorrência natural da espécie, em vegetação de transição entre o Cerrado e a Restinga. O experimento foi realizado no município de Morros-Maranhão, nos povoados Patizal, Recanto e Recurso, caracterizados por extensas áreas de vegetação de transição: Cerrado e Restinga, com ocorrência natural de mangabeira. Nos três povoados, selecionaram-se 45 mangabeiras-matrizes, das quais se mensuraram a altura total, altura do fuste, diâmetro do caule, volume de copa, número de ramos principais e secundários, e número de frutos. Coletaram-se 20 frutos por matriz e determinaram-se a massa, comprimento e diâmetro dos frutos, massa da polpa mais casca, rendimento de polpa, número e massa de sementes. Houve elevado grau de variabilidade para todas as variáveis estudadas, exceto para o rendimento de polpa (média $=86,69 \%$, mínimo $=76,75 \%$ e máximo $=91,11 \% ; \mathrm{CV}=3,51 \%)$. Há correlação positiva significativa de alta magnitude entre as variáveis massa do fruto e massa da polpa mais casca com o número de sementes ( $\mathrm{r}=0,01 ; \rho \leq 0,78$ e $\rho \leq 0,74$, respectivamente). Termos para indexação: Hancornia speciosa Gomes, seleções silvestres, biometria.
\end{abstract}

\footnotetext{
${ }^{1}$ (Paper 058-16) Received April 19, 2016. Accepted September 02, 2016.

${ }^{2}$ Doctoral candidate, Post Graduation Program in Agroecology, Agricultural Science Center, Maranhão State University, Brazil, E-mail: larissapvs@hotmail.com

${ }^{3}$ Professor, Doctor, Department of Agronomy and Plan Health, Agricultural Science Center, Maranhão State University, Brazil. E-mails: gusmaoaraujo50@gmail.com; hederbraun@gmail.com; aenesrocha@gmail.com; mario-mesquita51@hotmail.com

${ }^{4}$ Agronomy student, Maranhão State University, Brazil. E-mail: maryjane.nunes@hotmail.com
} 


\section{INTRODUCTION}

Brazil is a major fruit producer in the world, thanks to its territorial extension, geographic location, soil and climate conditions, taking third position in the world fruit production ranking (FAO, 2013). However, many native fruit species, with excellent nutritional and sensorial properties are not yet fully exploited (LIMA et al., 2015), as is the case for mangabeira (Hancornia speciosa Gomes) Apocynaceae.

Mangabeira plants grow spontaneously in the Southeast, Midwest, North and Northeast of Brazil, where it is most abundant, and its ripe fruit is highly appreciated for fresh consumption and/or industrialization (GANGA et al., 2010). The species has been highlighted because its fruit has a nutritional value higher than most commercially used native fruits (NASCIMENTO et al.. 2014).

Research reported on mangabeira has focused mainly on species propagation (LÉDO et al. 2007), medicinal properties (MARINHO et al. 2011), fruit characterization (PERFEITO et al. 2015) and the species population dynamics (LIMA, et al. 2013).

Mangabeira is a species that is still in domestication process, but it is at risk of extinction, due to accelerated devastation of the native mangabeira areas in the Brazilian Northeastern coast (SÁ et al., 2011), including the SavannahRestinga (coastal plains covered by marine deposits) vegetation transition zone in the State of Maranhão. There is little scientific information on general aspects of this species in its naturally occurring environment, particularly with respect to selections or superior genotypes, yield, production stability and fruit quality.

Information on mangabeira conservation and proper utilization, as well as superior genotype selection is crucial to improve crop management and yield. Based on this approach, this study aimed to characterize the mangabeira species from native selections in areas of natural occurrence in the Savannah-Restinga vegetation transition zone in the State of Maranhão, with emphasis on plant and fruit morphological characterization.

\section{MATERIAL AND METHODS}

The research was carried out in the villages of Recurso (02 $58^{\prime} 42.7^{\prime \prime} \mathrm{S}$ and 43 $51^{\prime} 12.7^{\prime \prime} \mathrm{W}$ ),

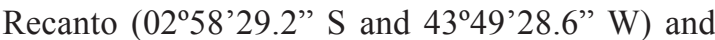
Patizal $\left(03^{\circ} 00^{\prime} 25.4^{\prime \prime} \mathrm{S}\right.$ and $\left.43^{\circ} 54^{\prime} 22.9^{\prime \prime} \mathrm{W}\right)$, in the Settlement Project Rio Pirangi, located in the municipality of Morros, which is part of the North Maranhense mesoregion, Rosario microregion and of the Munim river basin in the State of Maranhão. The climate is sub-humid, with average annual temperatures of $25-27^{\circ} \mathrm{C}$, relative humidity of 78$82 \%$, and rainfall between $1900-2300 \mathrm{~mm}$ year $^{-1}$. The soil at the Settlement Project is classified as Quartzipsamment and vegetation, as SavannahRestinga transition zone (NUGEO, 2015).

Forty five mangabeira plants with a minimum spacing of $10 \mathrm{~m}$ between plants were randomly selected in November 2014. They were identified by sequential numbers put on plates of ethylene vinyl acetate (E.V.A.). Plants numbered from 1 to 15 were in Patizal, from 16 to 30 in Recanto and from 31 to 45 in Recurso villages. The geographical coordinates of each plant was obtained using a Global Position System (GPS) receiver (Table 1).

Data collected were: stem diameter at $20 \mathrm{~cm}$ from ground level, total plant height (m), stem height $(\mathrm{m})$, number of primary and secondary branches, number of fruits on the plant and canopy volume $\left(\mathrm{m}^{3}\right)$, according to the methodology described by Freitas et al. (2012). The yield per plant was estimated by multiplying the number of fruits per plant by the average fruit weight per plant (GANGA et al., 2010) (Table 1). Twenty ripe fruits were collected per plant (on the ground). From these, twelve were randomly selected, totaling 540 fruits which were used for biometric analyses carried out in the Plant Science and Post Harvest Laboratory at Maranhão State University, in São Luís. The biometric analyses were performed by individual fruit, through measurements of longitudinal and transverse diameters $(\mathrm{cm})$, fruit mass (g) and the residue portions (seed and pulp plus fruit skin) (g) and counting seed number. The pulp yield (\%) was obtained by the ratio between the pulp mass plus fruit skin and fruit mass (GANGA et al., 2010).

The data were analyzed using descriptive statistics and were expressed as the mean \pm standard deviation. The existing relationship between the studied characteristics (45 observations) of plants and fruits were estimated by the Pearson correlation coefficient and the significance level of correlations was tested by the $t$-test up to $10 \%$ of probability. All statistical analyzes were performed with the statistical software SAEG, Version 9.1 (2007). 


\section{RESULTS AND DISCUSSION}

The descriptive analyses results for plant morphology showed that the plants had a mean height of $5.12 \mathrm{~m} \pm 0.12$, suggesting variation from tree to shrub size among the mangabeira natural populations. The overall averages were $74.76 \mathrm{~m}^{3}( \pm$ $5.65)$ for canopy volume, $20.54 \mathrm{~cm}( \pm 1.07)$ for the stem diameter, $0.73 \mathrm{~m}( \pm 0.06)$ for the stem height, $3( \pm 0.09)$ for the number of primary branches, 6 $( \pm 0.33)$ for the number of secondary branches and $280( \pm 16.42)$ for the number of fruits per selected plant (Table 2).

The average yield per plant was $5.99 \mathrm{~kg}$, in the range between $0.97 \mathrm{~kg}$ to $13.26 \mathrm{~kg}$ (Table 1). These results were higher than those obtained by Ganga et al. (2010), who reported average of 1.67 $\mathrm{kg}$ per plant, in the range between 0.09 and 7.89 $\mathrm{kg}$ for mangabeira variety Speciosa, from natural mangabeira populations in the States of Goiás, Tocantins, Mato Grosso, Mato Grosso do Sul and Bahia. This high fruit yield of the sampled plants in our experiment, which was carried out in unmanaged areas (without crowning, weed control and branches pruning, among others) probably is associated with the plant genetic potential and/or with the great species adaptation to the low fertility soils from the Savannah-Restinga vegetation transition zone in region of Morros.

Despite the proximity of mangabeira natural populations in Patizal, Recurso and Recanto villages, it was observed that there was a great variability for all plant morphological characteristics, resulting in high standard deviation (SD) and high coefficient of variation (CV\%) (Table 2). Such variations may possibly be explained by the mangabeira local management and population structure.

Studies with mangabeira natural populations reported considerable phenotypic variability to the morphological plant characteristics, particularly for total height, stem height, stem diameter and canopy volume. For instance, Ganga et al. (2010) described variations in the total plant height of the mangabeira from 1.5 to $10 \mathrm{~m}$ and variations in plant stem diameter from 34.38 to $5.73 \mathrm{~cm}$. On the other hand, Freitas et al. (2012), in research carried out in the municipality of Porto Nacional, State of Tocantins, described high variation for stem height, with minimum and maximum of 0 and $2.25 \mathrm{~m}$ respectively and high range for canopy volume, with a minimum of 4.4 and maximum to $102.21 \mathrm{~m}^{3}$.

Fruit biometrics showed large variability for all assessed parameters, except for the pulp yield which showed low coefficient of variation (Table 3 ).
The high variability observed for the fruit biometric characteristics can be explained because it is a non-domesticated species in its naturally occurring environment, with high heterogeneity.

With regards to fruit weight, the results were equivalent to those reported by Perfeito et al. (2015) who in a study to characterize fruits at different maturity stages described overall average of 28.71 $\mathrm{g}$, but were lower than those reported by Lima et al. (2015) who studied the mangabeira fruit growth in Savannah environment in the State of Minas Gerais, where the authors described fruit weight average of $38.77 \mathrm{~g}$. For this variable, the natural population of Recurso was noteworthy, with higher average fruit weight (23.32 g), followed by Patizal (21.63 g) and Recanto (17.43 g).

The mangabeira fruit length $(3.7 \mathrm{~cm})$ and width $(3.17 \mathrm{~cm})$ recorded in this study were lower than those sampled by Perfeito et al. (2015), who described averages of 3.88 to fruit length and $3.54 \mathrm{~cm}$ to fruit width and by Lima et al. (2015) who reported average of $6.71 \mathrm{~cm}$ to fruit length.

The pulp mass average of the mangabeira fruit was $0.62 \mathrm{~g}( \pm 18)$ and the overall average for pulp yield was $86.69 \%$ ( \pm 0.45$)$. This value is considered high when compared to other results, such as those reported by Ganga et al. (2010) (who described average of $82.68 \%$ ), Perfeito et al. (2015) (72,71\%), Nascimento et al. (2014) (85.93\%), Freitas et al. (2012) (49.73\%) and Souza et al. (2007) (85\%). Among the mangabeira populations sampled in Morros, the fruits from Patizal village had higher pulp yield (average $87.48 \%$ ) followed by Recurso (87.14\%) and Recanto (85.14\%).

Seed number and seed mass results were lower than those reported by similar studies such as Freitas et al. (2012) who reported average 16 seeds per fruit with average weight of $5.05 \mathrm{~g}$, and Perfeito et al. (2015) who described average of 6,07 g. Darrault and Schlindwein (2006) explained that the number of fruits per seed is a very variable characteristic, which is influenced by the frequency of pollinators, which, in turn, is related to the species diversity in the areas.

There was significant and high positive correlation between total plant height and canopy volume $(r=0.72 ; \rho \leq 0.01)$. Although to a lesser extent, there were also positive and significant correlation between total plant height and stem diameter $(r=0.3 ; \rho=0.05)$ and between total plant height and fruit diameter $(r=0.22 ; \rho \leq 0.10)$. There was no significant correlation between total plant height and other variables. Furthermore, there was significant and positive correlation between the number of primary and secondary branches $(r=0.5$; 
$\rho \leq 0.01$ ) (Table 4).

The number of fruits correlated only with the plant morphological variable number of secondary branches showing positive and significant correlation of only $0.30(\rho \leq 0.05)$. Despite the low magnitude of this correlation, we can conclude that there is a tendency that the higher the number of secondary branches, the higher also is the number of fruits.

There was a negative and significant correlation between stem height and fruit length ( $\mathrm{r}$ $=-0.25 ; \rho=0.05)$, and significant positive correlation between canopy volume and fruit diameter $(\mathrm{r}=0.43$; $\rho \leq 0.01$ ) (Table 4), indicating that there is a tendency that the greater the stem height, the less the fruit length; and the higher the canopy volume, the greater the fruit diameter.

The fruit mass was highly related to other dimensional fruit and seed characteristics (Table 4). Special emphasis is given to the high magnitude positive and significant correlation between the variables fruit weight and seed number $(r=0.78$; $\rho \leq 0.01)$ as well as between the seed number and pulp mass plus skin $(r=0.73 ; \rho \leq 0.01)$. These results are similar to those reported by Ganga et al. (2010), Freitas et al. (2012) and Nascimento et al. (2014). These results also show that with increased weight and more seeds, fruits tend to have larger amount of pulp, which is directly related to efficient pollination, since the mangabeira shows self incompatibility.

TABLE 1- Geographic coordinates from the selected mangabeira plants in Morros - Maranhão and their respective productions $(\mathrm{kg})$.

\begin{tabular}{|c|c|c|c|c|c|c|c|}
\hline Plant & $\begin{array}{c}\text { Latitude } \\
\text { (S) }\end{array}$ & $\begin{array}{l}\text { Longitude } \\
\text { (W) }\end{array}$ & $\begin{array}{c}\text { E. P.* } \\
(\mathrm{kg})\end{array}$ & Plant & Latitude (S) & Longitude (W) & $\begin{array}{r}\text { E. P.* } \\
(\mathrm{kg})\end{array}$ \\
\hline 1 & $03^{\circ} 00^{\prime} 25.5^{\prime \prime}$ & $43^{\circ} 54^{\prime} 23.5^{\prime \prime}$ & 6.85 & 24 & $02^{\circ} 58^{\prime} 28.7^{\prime \prime}$ & $43^{\circ} 49^{\prime} 30.1^{\prime \prime}$ & 2.74 \\
\hline 2 & $03^{\circ} 00^{\prime} 26.0^{\prime \prime}$ & $43^{\circ} 54^{\prime} 22.3^{\prime \prime}$ & 7.10 & 25 & $02^{\circ} 58^{\prime} 28.4^{\prime \prime}$ & $43^{\circ} 49^{\prime} 30.5^{\prime \prime}$ & 3.02 \\
\hline 3 & $03^{\circ} 00^{\prime} 26.0^{\prime \prime}$ & $43^{\circ} 54^{\prime} 20.9^{\prime \prime}$ & 4.46 & 26 & $02^{\circ} 58^{\prime} 28.8^{\prime \prime}$ & $43^{\circ} 49^{\prime} 31.6^{\prime \prime}$ & 3.76 \\
\hline 4 & $03^{\circ} 00^{\prime} 24.8^{\prime \prime}$ & $43^{\circ} 54^{\prime} 20.3^{\prime \prime}$ & 6.41 & 27 & $02^{\circ} 58^{\prime} 26.0^{\prime \prime}$ & $43^{\circ} 49^{\prime} 29.6$ '” & 2.17 \\
\hline 5 & $03^{\circ} 00^{\prime} 23.3^{\prime \prime}$ & $43^{\circ} 54^{\prime} 20.0^{\prime \prime}$ & 9.65 & 28 & $02^{\circ} 58^{\prime} 25.9 "$ & $43^{\circ} 49^{\prime} 28.7^{\prime \prime}$ & 1.86 \\
\hline 6 & $03^{\circ} 00^{\prime} 23.0^{\prime \prime}$ & $43^{\circ} 54^{\prime} 19.9^{\prime \prime}$ & 5.47 & 29 & $02^{\circ} 58^{\prime} 26.3^{\prime \prime}$ & $43^{\circ} 49^{\prime} 27.8^{\prime \prime}$ & 3.11 \\
\hline 7 & $03^{\circ} 00^{\prime} 23.4^{\prime \prime}$ & $43^{\circ} 54^{\prime} 19.0^{\prime \prime}$ & 5.63 & 30 & $02^{\circ} 58^{\prime} 25.3^{\prime \prime}$ & $43^{\circ} 49^{\prime} 27.2^{\prime \prime}$ & 3.58 \\
\hline 8 & $03^{\circ} 00^{\prime} 22.9^{\prime \prime}$ & $43^{\circ} 54^{\prime} 18.2^{\prime \prime}$ & 9.04 & 31 & $02^{\circ} 58^{\prime} 54.4^{\prime \prime}$ & $43^{\circ} 58^{\prime} 10.2^{\prime \prime}$ & 6.10 \\
\hline 9 & $03^{\circ} 00^{\prime} 21.2^{\prime \prime}$ & $43^{\circ} 54^{\prime} 18.7^{\prime \prime}$ & 9.43 & 32 & $02^{\circ} 58^{\prime} 56.9^{\prime \prime}$ & $43^{\circ} 53^{\prime} 11.1 "$ & 7.92 \\
\hline 10 & $03^{\circ} 00^{\prime} 21.1$ ' & $43^{\circ} 54^{\prime} 18.7^{\prime \prime}$ & 8.42 & 33 & $02^{\circ} 58^{\prime} 57.7^{\prime \prime}$ & $43^{\circ} 53^{\prime} 12.6^{\prime \prime}$ & 5.51 \\
\hline 11 & $03^{\circ} 00^{\prime} 20.5^{\prime}$ & $43^{\circ} 54^{\prime} 19.4^{\prime \prime}$ & 6.69 & 34 & $02^{\circ} 58^{\prime} 59.5^{\prime \prime}$ & $43^{\circ} 51^{\prime} 15.3^{\prime \prime}$ & 6.62 \\
\hline 12 & $03^{\circ} 00^{\prime} 19.4^{\prime \prime}$ & $43^{\circ} 54^{\prime} 20.0^{\prime \prime}$ & 5.88 & 35 & $02^{\circ} 59^{\prime} 00.3^{\prime \prime}$ & $43^{\circ} 53^{\prime} 17.3^{\prime \prime}$ & 3.90 \\
\hline 13 & $03^{\circ} 00^{\prime} 20.6^{\prime \prime}$ & $43^{\circ} 54^{\prime} 20.2^{\prime \prime}$ & 7.46 & 36 & $02^{\circ} 59^{\prime} 02.4^{\prime \prime}$ & $43^{\circ} 53^{\prime} 19.4^{\prime \prime}$ & 10.79 \\
\hline 14 & $03^{\circ} 00^{\prime} 20.6^{\prime \prime}$ & $43^{\circ} 54^{\prime} 20.3^{\prime \prime}$ & 10.47 & 37 & $02^{\circ} 59^{\prime} 03.2^{\prime \prime}$ & $43^{\circ} 53^{\prime} 18.7^{\prime \prime}$ & 6.20 \\
\hline 15 & $03^{\circ} 00^{\prime} 22.0^{\prime \prime}$ & $43^{\circ} 54^{\prime} 20.3^{\prime \prime}$ & 6.12 & 38 & $02^{\circ} 59^{\prime} 02.5^{\prime \prime}$ & $43^{\circ} 53^{\prime} 03.1$ ' & 4.77 \\
\hline 16 & $02^{\circ} 58^{\prime} 31.8^{\prime \prime}$ & $43^{\circ} 49^{\prime} 32.8^{\prime \prime}$ & 3.50 & 39 & $02^{\circ} 59^{\prime} 02.6^{\prime \prime}$ & $43^{\circ} 53^{\prime} 20.9$ ' & 9.28 \\
\hline 17 & $02^{\circ} 58^{\prime} 30.7^{\prime \prime}$ & $43^{\circ} 49^{\prime} 30.8^{\prime \prime}$ & 2.38 & 40 & $02^{\circ} 59^{\prime} 02.3 "$ & $43^{\circ} 53^{\prime} 20.9^{\prime \prime}$ & 13.26 \\
\hline 18 & $02^{\circ} 58^{\prime} 29.8^{\prime \prime}$ & $43^{\circ} 49^{\prime} 30.8^{\prime \prime}$ & 4.66 & 41 & $02^{\circ} 59^{\prime} 02.1$ "' & $43^{\circ} 53^{\prime} 19.7^{\prime \prime}$ & 5.54 \\
\hline 19 & $02^{\circ} 58^{\prime} 30.1^{\prime \prime}$ & $43^{\circ} 49^{\prime} 30.5^{\prime \prime}$ & 3.26 & 42 & $02^{\circ} 59^{\prime} 02.1 "$ & $43^{\circ} 53^{\prime} 19.6^{\prime \prime}$ & 13.26 \\
\hline 20 & $02^{\circ} 58^{\prime} 30.5^{\prime \prime}$ & $43^{\circ} 49^{\prime} 30.3^{\prime \prime}$ & 0.97 & 43 & 02059'00.7" & $43^{\circ} 53^{\prime} 21.2^{\prime \prime}$ & 10.16 \\
\hline 21 & $02^{\circ} 58^{\prime} 30.9^{\prime \prime}$ & $43^{\circ} 49^{\prime} 29.5^{\prime \prime}$ & 1.80 & 44 & $02^{\circ} 58^{\prime} 57.7^{\prime \prime}$ & $43^{\circ} 53^{\prime} 15.4^{\prime \prime}$ & 4.50 \\
\hline 22 & $02^{\circ} 58^{\prime} 29.5^{\prime \prime}$ & $43^{\circ} 49^{\prime} 29.8^{\prime \prime}$ & 3.25 & 45 & $02^{\circ} 58^{\prime} 57.6^{\prime \prime}$ & $43^{\circ} 53^{\prime} 15.4^{\prime \prime}$ & 9.20 \\
\hline 23 & $02^{\circ} 58^{\prime} 29.2^{\prime \prime}$ & $43^{\circ} 49^{\prime} 28.7^{\prime \prime}$ & 3.48 & & & & \\
\hline
\end{tabular}

*Estimated Producion 
TABLE 2- Descriptive statistics of the morphological characteristics of the mangabeira plants in areas of natural occurrence, in Morros, Maranhão State.

\begin{tabular}{|c|c|c|c|c|c|c|c|}
\hline \multirow{2}{*}{ Parameter } & PH (m) & $\operatorname{CV}\left(\mathrm{m}^{3}\right)$ & D20 (cm) & SHt (m) & MBN & SBN & FN \\
\hline & \multicolumn{7}{|c|}{ Patizal $(\mathrm{n}=15 \pm \mathrm{SD})$} \\
\hline Mean & $5.18 \pm 0.66$ & $79.72 \pm 41.07$ & $19.37 \pm 6.5$ & $0,45 \pm 0.36$ & $3 \pm 0.86$ & $8 \pm 2.42$ & $338 \pm 74.51$ \\
\hline \multirow[t]{2}{*}{ CV $(\%)$} & 12.87 & 51.51 & 33.61 & 79.46 & 30.78 & 30.25 & 22.01 \\
\hline & \multicolumn{7}{|c|}{ Recanto $(\mathrm{n}=15 \pm \mathrm{SD})$} \\
\hline Mean & $5.18 \pm 0.95$ & $77.17 \pm 42.20$ & $23.30 \pm 8.82$ & $0.86 \pm 0.59$ & $2 \pm 0.52$ & $6 \pm 1.87$ & $172 \pm 57.68$ \\
\hline \multirow[t]{2}{*}{ CV $(\%)$} & 18.43 & 54.68 & 37.86 & 68.67 & 20.93 & 30.82 & 33.45 \\
\hline & \multicolumn{7}{|c|}{ Recurso $(\mathrm{n}=15 \pm \mathrm{SD})$} \\
\hline Mean & $5.02 \pm 0.99$ & $67.39 \pm 31.06$ & $18.96 \pm 5.65$ & $0.89 \pm 0.15$ & $2 \pm 0.52$ & $5 \pm 1.64$ & $330 \pm 102.33$ \\
\hline \multirow[t]{2}{*}{$\mathrm{CV}(\%)$} & 19.71 & 46.09 & 29.82 & 16.83 & 20.38 & 29.67 & 30.95 \\
\hline & \multicolumn{7}{|c|}{ General $(\mathrm{n}=45 \pm \mathrm{SD})$} \\
\hline Mean & $5.12 \pm 0.86$ & $74.76 \pm 37.94$ & $20.54 \pm 7.23$ & $0.73 \pm 0.45$ & $3 \pm 0.65$ & $6 \pm 2.23$ & $280 \pm 110.19$ \\
\hline $\mathrm{CV} \%$ & 16.88 & 50.74 & 35.21 & 61.06 & 25.14 & 34.16 & 39.28 \\
\hline
\end{tabular}

$* \mathrm{PH}=$ Plant height, $\mathrm{CV}=$ Canopy Volume, $\mathrm{D} 20=$ Stem diameter at $20 \mathrm{~cm}$ ground level, $\mathrm{SHt}=$ Stem height, MBN $=$ Main branches number, $\mathrm{SBN}=$ Secondary branches number, $\mathrm{FN}=$ Fruit number per plant. Data are expressed as the mean \pm standard deviation. $\mathrm{CV}$ $\%=$ Coefficient of Variation.

TABLE 3- Descriptive statistics of the mangabeira fruit biometric characteristics in naturally occurrence areas in Morros, Maranhão State.

\begin{tabular}{|c|c|c|c|c|c|c|c|}
\hline & FM (g) & FL (cm) & FD (cm) & SN & SM (g) & PMS (g) & PY (\%) \\
\hline & \multicolumn{7}{|c|}{ Patizal $(n=15 \pm$ SD $)$} \\
\hline Mean & $21.6 \pm 3.3$ & $3.85 \pm 0.8$ & $3.30 \pm 0.9$ & $12 \pm 3.9$ & $2.79 \pm 0.8$ & $18.84 \pm 2.8$ & $87.48 \pm 3.1$ \\
\hline Min. & 17.03 & 3.16 & 2.82 & 6.00 & 1.80 & 15.04 & 80.54 \\
\hline Max. & 27.88 & 6.52 & 6.00 & 22.00 & 4.66 & 23.46 & 90.96 \\
\hline \multirow[t]{2}{*}{ CV $(\%)$} & 15.32 & 21.13 & 26.83 & 33.96 & 29.29 & 14.82 & 3.51 \\
\hline & \multicolumn{7}{|c|}{ Recanto $(\mathrm{n}=15 \pm \mathrm{SD})$} \\
\hline Mean & $17.43 \pm 4.8$ & $3.45 \pm 0.4$ & $3.00 \pm 0.3$ & $7 \pm 2.3$ & $2.57 \pm 0.9$ & $14.86 \pm 4.2$ & $85.46 \pm 3.7$ \\
\hline Min. & 9.09 & 2.76 & 2.33 & 3.00 & 0.91 & 8.19 & 76.75 \\
\hline Max. & 25.25 & 4.03 & 3.43 & 10.00 & 4.19 & 21.05 & 90.21 \\
\hline \multirow[t]{2}{*}{$\mathrm{CV}(\%)$} & 27.79 & 10.85 & 11.05 & 33.13 & 35.63 & 28 & 4.35 \\
\hline & \multicolumn{7}{|c|}{ Recurso $(\mathrm{n}=15 \pm \mathrm{SD})$} \\
\hline Mean & $23.32 \pm 4.2$ & $3.8 \pm 0.3$ & $3.19 \pm 0.3$ & $11 \pm 3.3$ & $3.01 \pm 0.8$ & $20.31 \pm 3.5$ & $87.14 \pm 1.8$ \\
\hline Min. & 13.01 & 3.12 & 2.61 & 6.00 & 1.56 & 11.45 & 84.16 \\
\hline Max. & 29.55 & 4.31 & 3.59 & 18.00 & 4.23 & 26.04 & 91.11 \\
\hline \multirow[t]{2}{*}{$\mathrm{CV}(\%)$} & 17.89 & 8.06 & 8.07 & 29.20 & 25.90 & 17.54 & 2.12 \\
\hline & \multicolumn{7}{|c|}{ General $(\mathrm{n}=45 \pm \mathrm{SD})$} \\
\hline Mean & $20.79 \pm 4.8$ & $3.70 \pm 0.6$ & $3.17 \pm 0.6$ & $9.91 \pm 3.9$ & $2.79 \pm 0.8$ & $18.00 \pm 4.2$ & $86.69 \pm 3.1$ \\
\hline CV \% & 22.95 & 15.19 & 17.91 & 38.82 & 29.86 & 23.19 & 3.51 \\
\hline
\end{tabular}

*Min. $=$ Minimum, Max. $=$ Maximum, $\mathrm{FM}=$ Fruit mass, $\mathrm{FL}=$ Fruit length, $\mathrm{FD}=$ Fruit diameter, $\mathrm{SN}=\mathrm{Seed}$ number, $\mathrm{SM}=\mathrm{Seed}$ mass, $\mathrm{PMS}=$ Pulp mass plus fruit skin, $\mathrm{PY}=$ Pulp yield. Data are expressed as the mean \pm standard deviation. $\mathrm{CV} \%=$ Coefficient of Variation. 
TABLE 4-Pearson's correlation among the mangabeira plants and fruit physical characteristics in three villages at the Morros municipally, Maranhão State ( $\mathrm{n}=45$ observation).

\begin{tabular}{|c|c|c|c|c|c|c|c|c|c|c|c|c|}
\hline & $\mathrm{CV}$ & $\mathrm{D} 20$ & $\mathrm{SH}$ & MB & SB & $\mathrm{FN}$ & FM & FL & FD & SN & SM & PM \\
\hline D20 & $0.36^{*}$ & & & & & & & & & & & \\
\hline $\mathrm{SH}$ & $0.09^{\mathrm{ns}}$ & 0.40 * & & & & & & & & & & \\
\hline $\mathrm{MB}$ & $0.13^{\mathrm{ns}}$ & $0.30 * *$ & $-0.02^{\mathrm{ns}}$ & & & & & & & & & \\
\hline $\mathrm{SB}$ & $0.27 * *$ & $0.24^{\circ}$ & $-0.14^{\mathrm{ns}}$ & $0.5^{*}$ & & & & & & & & \\
\hline $\mathrm{FN}$ & $0.08^{\mathrm{ns}}$ & $-0.13^{\mathrm{ns}}$ & $-0.18^{\text {ns }}$ & $0.10^{\mathrm{ns}}$ & $0.29 * *$ & & & & & & & \\
\hline FM & $0.17^{\mathrm{ns}}$ & $-0.16^{\mathrm{ns}}$ & $-0.18^{\mathrm{ns}}$ & $-0.15^{\mathrm{ns}}$ & $-005^{\mathrm{ns}}$ & $0.31 * *$ & & & & & & \\
\hline $\mathrm{FL}$ & $0.008^{\mathrm{ns}}$ & $-0.20^{\circ}$ & $-0.25 * *$ & $-0.16 n s$ & $-0.07^{\mathrm{ns}}$ & $0.12^{\mathrm{ns}}$ & $0.54 *$ & & & & & \\
\hline FD & $0.43 *$ & $0.04^{\mathrm{ns}}$ & $-0.05^{\mathrm{ns}}$ & $-0.14^{\mathrm{ns}}$ & $-0.03^{\mathrm{ns}}$ & $0.09^{\mathrm{ns}}$ & $0.52 *$ & $0.21^{\circ}$ & & & & \\
\hline $\mathrm{SN}$ & $0.26 * *$ & $-0.17^{\mathrm{ns}}$ & $-0.33 * *$ & $-0.09 \mathrm{~ns}$ & $0.01^{\mathrm{ns}}$ & $0.38^{*}$ & $0.78^{*}$ & $0.39 *$ & $0.59 *$ & & & \\
\hline $\mathrm{SM}$ & $0.22^{\circ}$ & $-0.11^{\mathrm{ns}}$ & $-0.21^{\circ}$ & $-0.23^{\circ}$ & $-0.03^{\mathrm{ns}}$ & $0.15^{\mathrm{ns}}$ & $0.76^{*}$ & $0.31 * *$ & $0.52 *$ & $0.76^{*}$ & & \\
\hline PM & $0.15^{\mathrm{ns}}$ & $-0.16^{\mathrm{ns}}$ & $-0.16^{\mathrm{ns}}$ & $-0.13^{\text {ns }}$ & $-0.05^{\mathrm{ns}}$ & $0.32 * *$ & $0.99 *$ & $0.56^{*}$ & $0.49 *$ & $0.74 *$ & $0.66^{*}$ & \\
\hline PY & $-0.10^{\mathrm{ns}}$ & $0.01^{\mathrm{ns}}$ & $0.02^{\mathrm{ns}}$ & $0.16^{\mathrm{ns}}$ & $0.02^{\mathrm{ns}}$ & $0.09^{\mathrm{ns}}$ & $0.03^{\text {ns }}$ & $0.22^{\circ}$ & $-0.19^{\mathrm{ns}}$ & $-0.20^{\circ}$ & $-0.57 *$ & $0.14^{\mathrm{ns}}$ \\
\hline
\end{tabular}

${ }^{*} \mathrm{CV}=$ Canopy volume, $\mathrm{SH}=$ Stem height, $\mathrm{MB}=$ Main branches number, $\mathrm{SB}=$ Secondary branches number, $\mathrm{D} 20=$ Stem diameter at $20 \mathrm{~cm}$ ground level, $\mathrm{FN}=$ Fruit number, $\mathrm{FM}=$ Fruit mass, $\mathrm{FL}=$ Fruit length, $\mathrm{FD}=$ Fruit diameter, $\mathrm{SM}=\mathrm{Seed}$ mass, NS $=$ Number of seeds per fruit, $\mathrm{PM}=$ Pulp mass plus skin, $\mathrm{PY}=$ Pulp yield. $\mathrm{ns},{ }^{*},{ }^{* *},{ }^{\circ}=$ not significant, significant at $1 \%, 5 \%$ and $10 \%$, respectively.

\section{CONCLUSIONS}

There is a high degree of phenotypic variability for mangabeira plant and fruit characteristics, except for the pulp yield.

These results show the possibility to use mangabeira fruit biometric characteristics to select plants from natural selections with high genetic potential and great adaptation capacity to adverse soil and climate conditions.

\section{REFERENCES}

DARRAULT, R.O.; SCHLINDWEIN, C. A cultura da mangaba. In: SILVA JÚNIOR, J.F.; LÉDO, A.S. Polinização. Aracajú: Embrapa Tabuleiros Costeiros, 2006. p.44-56.

FAO. Food and Agriculture Organization of the United Nations. 2013. Disponível em: $<$ http://faostat.fao.org/site/609/DesktopDefault. aspx?PageID=609\#ancor $>$. Acesso em: 14 nov. 2015.
FREITAS, M.K.C.; COIMBRA, R.R.; AGUIAR, G.B.; AGUIAR, C.B.N.; CHAGAS, D.B.; FERREIRA, W.M.; OLIVEIRA, R.J. Variabilidade fenotípica e caracterização morfológica de uma população natural de Hancornia speciosa Gomes. Bioscience Journal, Uberlândia, v.28, n.5, p.833841, 2012.

GANGA, R.M.D.; FERREIRA, G.A.; CHAVES, L.J.NAVES, R.V.; NASCIMENTO, J.L. Caracterização de frutos e árvores de populações naturais de Hancornia speciosa Gomes do cerrado. Revista Brasileira Fruticultura, Jaboticabal, v.32, n.1, p.101-113, 2010.

LÉDO, A.S.; SECA, G.S.V.; BARBOZA, S.B.S.C.; SILVA JÚNIOR, J. F. Crescimento inicial de mangabeira (Hancornia speciosa Gomes) em diferentes meios de germinação in vitro. Ciência e Agrotecnologia, Lavras, v.31, n.4, p.989-993, 2007.

LIMA, I.L.P.; SCARIOT, A.; GIROLDO, A.B. Sustainable harvest of mangaba (Hancornia speciosa) fruits in northern Minas Gerais, Brazil. Economic Botany, New York, v.67, n.3, p.234-243, 2013. 
LIMA, J.P.; RODRIGUES, L.F.; MONTEIRO, A.A.D.P.; BOAS, E.V.B.V. Climacteric pattern of mangaba fruit (Hancornia speciosa Gomes) and its responses to temperature. Scientia Horticulturae, New York, v.59, n.9, p.1-5, 2015.

MARINHO, D.G.; ALVIANO, D.S.; MATHEUS, M.E.; ALVIANO, C.S.; FERNANDES, P.D. The latex obtained from Hancornia speciosa Gomes possesses anti-inflammatory activity. Journal of Ethnopharmacology, Thurmaston, v.135, n.2, p.530-537, 2011.

NASCIMENTO, R.S.M.; CARDOSO, J.A.; COCOZZA, F.D.M. Caracterização física e físicoquímica de frutos de mangabeira (Hancornia speciosaGomes) no oeste da Bahia. Revista Brasileira de Engenharia Agrícola e Ambiental, Campina Grande, v.18, n.8, p.856-860, 2014.

NUGEO - Núcleo Geoambiental. Atlas do Maranhão. São Luís: Laboratório de Geoprocessamento/ GEPLAN-UEMA, 2015. 42p.
PERFEITO, D.G.A.; CARVALHO, N.LOPES, M.C.M.; SCHMIDT, F.L. Caracterização de frutos de mangabas (Hancornia speciosa Gomes) e estudo de processos de extração da polpa. Revista de Agricultura Neotropical, Cassilândia, v.2, n.3, p.1-7, 2015.

SÁ, A.J.; LÉDO, A.S.; LÉDO, C.A.S. Conservação in vitro de mangabeira da região nordeste do Brasil. Revista Ciência Rural, Santa Maria, v.41, n.1, p.57- 62, 2011.

SAEG. Sistema para análises estatística. Versão 9.1. Viçosa: Fundação Arthur Bernardes, 2007.

SOUZA, F.G.; FIGUEIREDO, R.W.; ALVES, R.L.; MAIA, G.A.; ARAÚJO, I.A. Qualidade póscolheita de frutos de diferentes clones de mangabeira (Hancorniaspeciosa Gomes). Revista Ciência e Agrotecnologia, Lavras, v.31, n.5, p.1499-1454, 2007. 